\title{
ANALISIS FAKTOR-FAKTOR YANG MEMPENGARUHI ADOPSI APLIKASI UBER SEBAGAI PENYEDIA JASA TRANSPORTASI DI SURABAYA
}

\author{
Edwin Hendrani $^{1}$, Rinabi Tanamal ${ }^{2}$ \\ ${ }^{1,2}$ Program Studi Teknik Informatika, Universitas Ciputra Surabaya \\ Email: ehendrani@student.ciputra.ac.id; r.tanamal@ciputra.ac.id
}

\begin{abstract}
Abstrak: Seiring berjalannya waktu, Teknologi Informasi dan Komunikasi (TIK) di dunia ini semakin berkembang dengan pesat. Permintaan masyarakat akan kebutuhan jasa transportasi semakin tinggi. Kemajuan internet dan canggihnya telepon genggam semakin lama semakin canggih, yang membuat lebih nyaman dan efisiensi untuk memanjakan masyarakat. Dari fenomena tersebut lahirlah Uber. Penelitian ini menggunakan teori Technology Acceptance Model (TAM) dengan populasi user Uber Kota Surabaya Penelitian ini bertujuan untuk mengetahui faktor-faktor yang mempengaruhi adopsi aplikasi Uber sebagai penyedia jasa Transportasi di Surabaya. Hasil yang diperoleh setelah di analisis oleh peneliti adalah kepercayaan pengguna dalam mengadopsi aplikasi Uber yang sangat berpengaruh signifikan terhadap keinginan seseorang untuk menggunakan aplikasi Uber.
\end{abstract}

Kata kunci: Jasa transportasi, Uber, TAM (Technology Acceptance Model).

\begin{abstract}
As time goes by, Information Communication and Technology (ICT) in this world is growing rapidly. The demand from the public on transportation service is increasing. The evolution of the Internet, i.e. quicker, more stable and reliable, and also the smartness of mobile phone nowadays have turned the public to be more efficient and convenient. From this phenomenal event, UBER was born. This research is using Technology Acceptance Model (TAM) theory based on UBER users in Surabaya, Indonesia. The purpose of this research is to identify any factors that influence the adoption of the UBER application as a provider of transportation services in Surabaya, Indonesia. The results obtained after being analysed by the researchers concludes that the users' trust in the UBER application itself has a significant effect on the public's desire to use and trust the application.
\end{abstract}

Keywords: Transportation services, Uber, TAM (Technology Acceptance Model).

\section{PENDAHULUAN}

Perkembangan Teknologi semakin lama semakin muktahir, oleh karena itu manusia semakin membutuhkan akan suatu konsep dan mekanisme dalam proses pertukaran barang dan/atau jasa dengan cara memanfaatkan internet sebagai media komunikasi dan transaksi. Kemajuan internet akhirnya harus mampu berperan tinggi dan sangat luas dalam operasional masyarakat dan bisnis, dengan internet pelaku tidak lagi mengalami kesulitan dalam memperoleh informasi apapun. Sehingga, informasi harus disaring untuk mendapatkan informasi apapun yang tepat dan relevan dalam dunia bisnis dan lainnya seperti metode E-Business.

E-Business kegiatan bisnis yang dilakukan secara otomatis dengan menggunakan system informasi komputer. E-Business memmungkin suatu perusahaan untuk berhubungan dengan system pemprosesan data internal dan eksternal secara lebih efisien dan fleksibel. Sampai saat ini internet merupakan infrastruktur yang ideal untuk menjalan bisnis berbasis bisnis sehingga istilah $e$-Business pun menjadi identik, dengan menjalankan bisnis di internet. Bisnis mengandalkan pertemuan antar pembisnis seperti rapat yang akan di tempat khusus atau sekedar untuk mengirimkan dokumen atau barang penting perusahaan atau perorangan. E-Business mengandalkan media internet sebagai sarana untuk memperoleh tujuannya.

Sekarang ini banyak orang yang menggunakan metode E-Business sebagai media bisnis. Salah satu media yang digunakan adalah Uber. Uber adalah sebuah aplikasi yang menghubungkan penyedia jasa transportasi (dalam hal ini adalah mobil) dengan permintaan akan jasa tersebut.

Peneliti mencoba menganilisis adopsi Uber sebagai media bisnis dengan menggunakan kerangka kerja Technology Acceptance Model (TAM). Peneliti memilih menggunakan kerangka kerja TAM karena prinsip Parsimony dalam mengembangkan model persepsi user terhadap adopsi suatu teknologi.

\section{LANDASAN TEORI}

\section{TAM (Technology Acceptance Model)}

TAM merupakan adaptasi dari TRA yang diperkenalkan oleh Davis pada tahun 1986 dalam jurnal [1]. Tujuan TAM lebih dikhususkan untuk menjelaskan perilaku para pengguna komputer 
(computer usage behavior). TAM menggunakan TRA sebagai dasar teoritikal untuk menspesifikasi hubungan kausal antara dua kunci kepercayaan (belief) yaitu persepsi manfaat (Perceive Usefulness) dan persepsi kemudahan penggunaan (Perceieved Ease of Use). TAM jauh lebih spesifik dibandingkan dengan TRA, karena TAM ditujukan hanya untuk perilaku penggunaan teknologi komputer. Model TAM ini tidak hanya bisa untuk memprediksi, namun juga bisa menjelaskan sehingga peneliti dan para praktisi bisa mengidentifikasi mengapa suatu faktor tidak diterima dan memberikan kemungkinan langkah yang tepat.

\section{Trust}

Kepercayaan adalah keyakinan bahwa seseorang akan menemukan apa yang diinginkan pada mitra pertukaran. Kepercayaan melibatkan kesediaan seseorang untuk bertingkah laku tertentu karena keyakinan bahwa mitranya akan memberikan apa yang ia harapkan dan suatu harapan yang umumnya dimiliki seseorang bahwa kata, janji atau pernyataan orang lain dapat dipercaya[2]. Pengukuran kepercayaan menurut[3]adalah kinerja perusahaan secara keseluruhan memenuhi harapan, pelayanan yang diberikan perusahaan secara konsisten terjaga kualitasnya, percaya bahwa perusahaan tersebut akan bertahan lama.

\section{Computer Self Efficacy}

Dalam bidang sistem informasi, computer selfefficacy menunjuk pada penilaian pribadi (selfassessment) atas kemampuan untuk melakukan ketrampilan komputer untuk menyelesaikan suatu tugas. Oleh sebab itu computer self-efficacy mempengaruhi kemudahan penggunaan yang dirasakan (perceived ease of use) menurut Davis pada tahun 1986 di jurnal[4]. Menurut Saadé (2009) computer self efficacy didefinisikan sebagai keyakinan individu tentang atau kemampuannya untuk berhasil melaksanakan perilaku yang diperlukan untuk menghasilkan hasil yang diinginkan

Dari uraian di atas, maka dapat disimpulkan bahwa computer self efficacy mengacu pada keyakinan individu bahwa individu tersebut dapat menggunakan komputer untuk menyelesaikan sebuah pekerjaan dengan menggunakan komputer.

\section{Perceived Ease of Use (PEOU)}

Menurut Davis pada tahun 1986 dalam jurnal [1] mendefinisikan kemudahan penggunaan (perceived Ease of use) sebagai suatu tingkatan dimana seseorang percaya bahwa penggunaan system tertentu dapat mengurangi usaha seseorang dalam mengerjakan sesuatu.

\section{Perceived Usefullness (PU)}

Perceived Usefullness adalah keadaan dimana persepsi pengguna tentang kegunaan dari sistem tersebut bagi pengguna menunjukkan bahwa perceived ease of use dengan pemakaian (actual use) mempunyai hubungan yang kuat menurut Davis pada tahun 1986 dalam jurnal [1]. Berdasarkan definisi tersebut dapat diartikan bahwa kemanfaatan dari penggunaan teknologi dapat meningkatkan kinerja orang yang menggunakannya.

\section{Behavioral Intention to Use (BITU)}

Menurut Davis pada tahun 1986 dalam jurnal [1], behavioral intention to use atau niat perilaku untuk menggunakan adalah kecenderungan perilaku untuk tetap menggunakan suatu teknologi. Tingkat penggunaan sebuah teknologi komputer pada seseorang dapat diprediksi dari sikap perhatiannya terhadap teknologi tersebut, misalnya keinginan menambah peripheral pendukung, motivasi untuk tetap menggunakan, serta keinginan untuk memotivasi pengguna lain.

\section{TAM untuk Uber}

Uber merupakan jasa perantara penyedia taxi premium dengan menggunakan program khusus pemesanan taxi yang menghubungkan konsumen dengan driver Uber, dapat diakses melalui smartphone maupun komputer yang terhubung ke jaringan internet. Model yang dikembangkan untuk penelitian ini telah dimodifikasi sesuai dengan kebutuhan penelitian seperti pada Gambar 1.

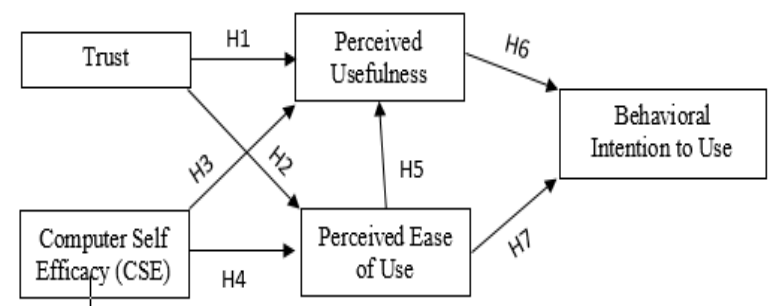

Gambar 1. Model TAM untuk Uber

\section{Uber}

Uber merupakan jasa perantara penyedia taxi premium dengan menggunakan program khusus pemesanan taxi yang menghubungkan konsumen dengan driver Uber, dapat diakses melalui smartphone maupun komputer yang terhubung ke jaringan internet. Program software yang disediakan sangat membantu para konsumen dalam memberikan informasi tentang: jarak tempuh ke lokasi tujuan, perkiraan tarif biaya, pembayaran ongkos taxi via kartu kredit, dan melihat profil driver Uber terdekat 
yang sedang dalam posisi standby dapat dihubungi. Pada akhir Tahun 2014 Uber mulai beroperasi di kota-kota besar Indonesia seperti Jakarta, Bandung, Bali, dan Surabaya [5].

\section{Variabel}

Variabel merupakan variasi dari objek penelitian, misalnya saja tinggi manusia dan divariasikan dengan umur atau berat badan yang dimilikinya. Karakter yang dapat diobservasi dari unit amatan yang merupakan suatu pengenal atau atribut dari sekelompok objek. Maksud dari variabel tersebut adalah terjadinya variasi antara objek yang satu dengan objek yang lainnya dalam kelompok tertentu. Macam-macam Variabel dan contohnya adalah sebagai berikut [6]:

- Variabel Independen (Variabel Bebas) adalah variabel yang mempengaruhi atau sebab perubahan timbulnya variabel terikat (dependen). Variabel Independen disebut juga dengan variabel perlakuan, kausa, risiko, variabel stimulus, antecedent, variabel pengaruh, treatment, dan variabel bebas. Dapat dikatakan variabel bebas karena dapat mempengaruhi variabel lainnya.

- Variabel Dependen (Variabel Terikat) adalah variabel yang dipengaruhi, akibat dari adanya variabel bebas. Dikatakan sebagai variabel terikat karena variabel terikat dipengaruhi oleh variabel independen (variabel bebas). Variabel Despenden disebut juga dengan variabel terikat, variabel output, Konsekuen, variabel tergantung, kriteria, variabel terpengaruh, dan variabel efek.

\section{PERANCANGAN DAN PEMBANGUNAN}

\section{Perumusan Hipotesis}

Hipotesis merupakan dugaan sementara yang diberikan peneliti untuk diuji apakah sesuai dengan hasil yang diberikan atau tidak. Adapun hipotesis untuk penelitian ini ditunjukkan pada Tabel 1.

Tabel 1. Hipotesis Penelitian

\begin{tabular}{|c|c|}
\hline Hipotesis & Hipotesis Penelitian \\
\hline $\mathrm{H} 1$ & $\begin{array}{l}\text { Diduga kepercayaan teknologi (Trust) Uber } \\
\text { secara signifikan berpengaruh terhadap persepsi } \\
\text { kemanfaatan (Perceived Usefulness/PU) }\end{array}$ \\
\hline $\mathrm{H} 2$ & $\begin{array}{l}\text { Diduga kepercayaan teknologi (Trust) Uber se- } \\
\text { cara signifikan berpengaruh terhadap kemudah- } \\
\text { an menggunakan Uber (Perceived Ease of } \\
\text { Use/PEOU) }\end{array}$ \\
\hline H3 & $\begin{array}{l}\text { Diduga persepsi kemampuan diri terhadap } \\
\text { computer (Computer Self Efficacy/CSE) secara } \\
\text { signifikan berpengaruh terhadap persepsi ke- } \\
\text { manfaatan (Perceived Usefulness/PU) }\end{array}$ \\
\hline
\end{tabular}

\begin{tabular}{cl}
\hline Hipotesis & \multicolumn{1}{c}{ Hipotesis Penelitian } \\
\hline H4 & $\begin{array}{l}\text { Diduga persepsi kemampuan diri terhadap } \\
\text { computer (Computer Self Efficacy/CSE) secara } \\
\text { signifikan berpengaruh terhadap kemudahan }\end{array}$ \\
& menggunakan Uber (Perceived Ease of Use/ \\
& PEOU) \\
H5 & Diduga persepsi kemudahan menggunakan \\
& Uber (Perceived Ease Of Use/PEOU) secara \\
& signifikan berpengaruh terhadap persepsi \\
kemanfaatan (Perceived Usefulness/PU) \\
Diduga persepsi kemanfaatan (Perceived Use- \\
fulness/PU) secara signifikan berpengaruh ter- \\
hadap persepsi sikap niat/keinginan untuk \\
menggunakan Uber (Behavioral Intention to \\
Use/BITU) \\
Diduga persepsi kemudahaan menggunakan \\
(Perceived Ease of Use/PEOU) secara signi- \\
fikan berpengaruh terhadap persepsi niat/ke- \\
inginan untuk menggunakan Uber (Behavioral \\
Intention to Use/BITU)
\end{tabular}

Seiring dengan meningkatnya kepercayaan konsumen maka secara berpengaruh secara signifikan terhadap persepsi kemanfaatan dalam menggunakan. Selain itu pula kepercayaan berpengaruh pula terhadap kemudahan menggunakan aplikasi uber tersebut. Kemampuan seseorang dalam menggunakan aplikasi uber bermacam-macam dengan itu dalam memanfaatkan aplikasi tersebut dapat diukur juga. Setiap orang memiliki kemampuan yang lebih atau rendah dalam menggunakan aplikasi, jadi kemampuan terhadap kemudahan menggunakan dapat di ukur. Dengan begitu kemanfaatan dan kemudahan menjadi salah satu kecenderungan perilaku konsumen dalam menggunakan suatu aplikasi tersebut.

\section{Instrumen Penelitian}

Dalam penelitian terhadap adopsi Uber ini, metode pengumpulan data yang digunakan adalah pembagian secara online. Proses pengumpulan data dilakukan dengan membagikan kuisioner terhadap responden yang berisi pertanyaan-pertanyaan. Jawaban yang diperoleh dari kuisioner tersebut akan diukur menggunakan skala Likert. Skala Likert adalah ukuran-ukuran berjenjang. Skala penilaian, misalnya, merupakan skala untuk menilai sesuatu yang pilihannya berjenjang, misalnya $0,1,2,3,4,5,6,7,8$, 9,10. Skala Likert juga merupakan alat untuk mengukur (mengumpulkan data dengan cara "mengukur-menimbang") yang "itemnya" (butir-butir pertanyaannya) berisikan (memuat) pilihan yang berjenjang.

Populasi adalah wilayah generalisasi yang terdiri dari objek/subjek yang mempunyai kualitas dan karakteristik tertentu, yang ditetapkan oleh peneliti untuk dipelajari dan kemudian ditarik kesimpulan [7]. 
Sampel adalah bagian suatu subjek atau objek yang mewakili populasi. Pengambilan sampel harus sesuai dengan kualitas dan karakteristik suatu populasi. Pengambilan sampel yang tidak sesuai dengan kualitas dan karakteristik suatu populasi akan menyebabkan suatu penelitian menjadi bias, tidak dapat dipercaya, dan kesimpulannya pun bisa keliru. Hal ini karena tidak dapat mewakili populasi [7].

Uji yang digunakan dalam penelitian ini adalah Uji Outlier, Uji Normalitas, Uji Validitas, dan Uji Relibilitas. Uji Outlier dan Uji Normalitas tergabung dalam Uji Asumsi. UJi Asusmsi ini diolah dengan menggunakan software SPSS versi 23. Data responden diperoleh dari 126 pengguna Uber di Surabaya.

\section{Uji Asumsi}

\begin{tabular}{ll}
\hline Goodness of Fit & Interpretasi \\
\hline Chi Square & $\begin{array}{l}\text { Diharapakan nilai kecil } \\
\text { dengan P>0.05 }\end{array}$ \\
$\begin{array}{l}\text { Normed Chi Square } \\
\text { Root Mean Square Residual } \\
\text { (RMR) }\end{array}$ & $\begin{array}{l}<3 \\
\text { Mendekati nol }\end{array}$ \\
$\begin{array}{l}\text { Goodness of Fit Index (GFI) } \\
\text { Adjusted GFI (AGFI) }\end{array}$ & $>0.90$ \\
$\begin{array}{l}\text { Normal Fit Index (NFI) } \\
\text { Incremental Fit Index (IFI) }\end{array}$ & $>0.90$ \\
$\begin{array}{l}\text { Comparative Fit Index (CFI) } \\
\text { Root Mean Square Error of } \\
\text { Application (RMSEA) }\end{array}$ & $<0.05$ (Sangat baik), \\
& $\begin{array}{l}0.05-0.08 \text { (Berada dalam } \\
\text { batas wajar), }\end{array}$ \\
& $>0.1$ (Model tidak baik), \\
& (Kline, 2011). \\
\hline
\end{tabular}

Uji Outlier adalah kasus atau data yang memiliki karakteristik unik yang terlihat sangat berbeda jauh dari observasi-observasi lainnya dan muncul dalam bentuk nilai ekstrim baik untuk sebuah variabel tunggal atau variabel kombinasi. Apabila ditemukan outliers, maka data yang bersangkutan harus dikeluarkan dari perhitungan lebih lanjut. Menurut Hair dalam Ghozali (2006:36) untuk kasus sampel kecil (kurang dari 80), maka standar skor dengan nilai \pm 2.5 dinyatakan outlier. Untuk sampel besar standar skor dinyatakan outlier jika nilainya pada kisaran 3 sampai 4.

Uji Normalitas bertujuan untuk menguji apakah dalam suatu model regresi linier variabel penganggu atau residual memiliki distribusi normal. Data yang baik adalah data yang memiliki pola distribusi normal. Uji normalitas bertujuan untuk menguji apakah dalam model regresi, variabel pengganggu atau residual memiliki distribusi normal. Model regresi yang baik adalah memiliki distribusi data normal atau penyebaran data statistik pada sumbu diagonal dari grafik distribusi normal [8] dalam jurnal [9]

\section{Uji Validitas}

Validitas adalah tingkat keandalan dan kesahihan alat ukur yang digunakan. Intrumen dikatakan valid berarti menunjukkan alat ukur yang dipergunakan untuk mendapatkan data itu valid atau dapat digunakan untuk mengukur apa yang seharusnya di ukur [10]. Tolak ukur instrumen dapat dinyatakan valid apabila nilai signifikansinya $<0.05$.

\section{Uji Reliabilitas}

Relibilitas adalah suatu tingkatan yang mengukur konsistensi hasil, jika dilakukan pengukuran berulan pada suatu karakteristik. Pengujian relibilitas dapat dihitung dengan menggunakan Cronbach alpha. Variabel dapat dikatakan valid apabila nilai dari Cronbach alpha >0,70.

\section{Analisis Hubungan}

Korelasi merupakan teknik analisis yang termasuk dalam salah satu teknik pengukuran asosiasi/ hubungan (measures of association).

\section{Analisis Jalur (Path Analysis)}

Analisi jalur (Path Analysis) merupakan pengembangan statistik regresi, sehingga analisis regresi dapat dikatakan sebagai bentuk khusus analisis jalur. Analisis jalur digunakan untuk melukiskan dan menguji model hubungan antar variabel yang berbentuk sebab akibat [11].

\section{Uji Model Fit}

Uji model fit dilakukan setelah uji path diagram selesai. Uji model fit digunakan untuk mengukur kesesuaian input observasi dengan prediksi dari model yang diajukan [8]. Ada 9 aspek yang harus dipenuhi, yaitu:

\section{Penerapan dan Pengujian}

Dalam penelitian ini, populasi yang diambil oleh peneliti adalah pengguna Uber di Surabaya. Teknik pengambilan sampel menggunakan non probability sampling dengan metode purposive sampling dimana metode purposive merupakan metode penetapan responden untuk dijadikan sampel berdasarkan kriteria-kriteria tertentu [12]. Kriteria yang diambil oleh peneliti dalam penelitian ini adalah para pengguna Uber di Surabaya. Kriteria yang diambil oleh peneliti dalam penelitian ini adalah para pengguna Uber di Surabaya. Jumlah sampel yang akan digunakan adalah sebanyak 126 orang. Metode penyebaran kuesioner dalam penelitian ini menggunakan survey online dan memperoleh jumlah sampel sebanyak 126 
sampel. Survei dilakukan dengan menggunakan google form. Dalam penelitian ini, karakteristik responden dibagi menjadi empat pertanyaan pokok. Adapun Tabel 2, 3, 4, \& 5 menerangkan mengenai jenis kelamin responden, Usia Responden, Pendidikan Responden, dan Penggunaan Aplikasi.

Tabel 2. Jenis Kelamin Responden

\begin{tabular}{lcc}
\hline \multicolumn{1}{c}{ Valid } & Frequency & Percent \\
\hline Laki-laki & 79 & 62,7 \\
Perempuan & 47 & 37,3 \\
\hline Total & 126 & 100,0 \\
\hline
\end{tabular}

Tabel 3. Usia Responden

\begin{tabular}{lcc}
\hline \multicolumn{1}{c}{ Valid } & Frequency & Percent \\
\hline $18-23$ thn & 84 & 66,7 \\
$24-28$ thn & 30 & 23,8 \\
$29-34$ thn & 10 & 7,9 \\
$35-40$ thn & 1 &, 8 \\
$>40$ thn & 1 &, 8 \\
\hline Total & 126 & 100,0 \\
\hline
\end{tabular}

Tabel 4. Pendidikan Responden

\begin{tabular}{lcc}
\hline \multicolumn{1}{c}{ Valid } & Frequency & Percent \\
\hline SMA/Sederajat & 46 & 36,5 \\
Diploma & 3 & 2,4 \\
S1 & 73 & 57,9 \\
Pasca Sarjana & 4 & 3,2 \\
\hline Total & 126 & 100,0 \\
\hline
\end{tabular}

Tabel 5. Penggunaan Responden

\begin{tabular}{lcc}
\hline Valid & Frequency & Percent \\
\hline 1-2 kali per-bulan & 99 & 78,6 \\
3-4 kali per-bulan & 16 & 12,7 \\
>5 per-bulan & 11 & 8,7 \\
\hline Total & 126 & 100,0 \\
\hline
\end{tabular}

\section{Uji Asumsi}

\section{Uji Outlier}

Untuk zscore dari masing-masing variabel $\mathrm{T}$, PR, PU, PEOU, dan ITU yang diuji sudah memenuhi standar yang ditentukan.

\section{Uji Normalitas}

Tabel 6. Skewness dan Kurtosis Normalista

\begin{tabular}{|c|c|c|c|c|}
\hline Indikator & Mean & Std. Dev. & Skewness & Kurtosis \\
\hline \multicolumn{5}{|c|}{ Perceived Usefulness } \\
\hline PU1 & 3.75 & 0.83 & -0.76 & 1.41 \\
\hline PU2 & 3.67 & 0.89 & -0.44 & 0.45 \\
\hline PU3 & 3.44 & 0.96 & -0.22 & 0.19 \\
\hline PU4 & 4.00 & 0.88 & -0.77 & 0.72 \\
\hline \multicolumn{5}{|c|}{ Perceived Ease of Use } \\
\hline$\overline{\text { PEOU1 }}$ & 3.72 & 0.82 & -0.47 & 0.71 \\
\hline PEOU2 & 3,60 & 0.84 & -0.45 & 0.45 \\
\hline PEOU3 & 3.60 & 0.90 & -0.57 & 0.684 \\
\hline PEOU4 & 3.81 & 0.81 & -0.61 & 1.03 \\
\hline
\end{tabular}

\begin{tabular}{lcccc}
\hline Indikator & Mean & Std. Dev. & Skewness & Kurtosis \\
\hline BITU1 & 3.74 & 0.95 & -0.73 & 0.58 \\
BITU2 & 3.62 & 0.91 & -0.45 & 0.29 \\
BITU3 & 3.75 & 0.87 & -0.66 & 0.93 \\
BITU4 & 3.69 & 1.00 & -1.01 & 0.95 \\
\hline Trust & & & & \\
\hline T1 & 3.68 & 0.90 & -0.68 & 0.85 \\
T2 & 3.57 & 0.89 & -0.58 & 0.67 \\
T3 & 3.52 & 0.85 & -0.46 & 0.95 \\
T4 & 3.49 & 0.93 & -0.60 & 0.43 \\
\hline Computer Self Efficacy & & & \\
\hline CSE1 & 3.40 & 0.88 & -0.33 & 0.41 \\
CSE2 & 3.48 & 0.86 & -0.21 & 0.43 \\
CSE3 & 3.63 & 0.79 & -0.66 & 1.45 \\
CSE4 & 3.80 & 0.84 & -0.80 & 1.41 \\
\hline
\end{tabular}

\section{Uji Validitas}

Uji Validitas adalah suatu tingkatan yang mengukur karakteristik yang ada di dalam fenomena dalam penyelidikan. Sedangkan menurut [10] Uji Validitas adalah suatu langkah pengujian yang dilakukan terhadap isi (content) dari suatu instrumen, dengan tujuan untuk mengukur ketepatan instrumen yang digunakan dalam suatu penelitian. Hasil Uji dapat dikatakan valid apabila memiliki nilai koefisien signifikasinya $<0,05$.

Tabel 9. Uji Pearson variable Perceived Usefulness

\begin{tabular}{llccccc}
\multicolumn{7}{c}{ Correlations } \\
\hline T_PU & Pearson &, $859^{* * *}$ &, $884^{* *}$ &, $827^{* *}$ &, $868^{* *}$ & 1 \\
& Correlation & & & & & \\
& Sig. (2-tailed) &, 000 &, 000 &, 000 &, 000 & \\
N & 126 & 126 & 126 & 126 & 126 \\
\hline **. Correlation is significant at the 0.01 level (2-tailed). &
\end{tabular}

Tabel 10. Uji Pearson variable Perceived Ease of Use

\begin{tabular}{cccccc}
\multicolumn{7}{c}{ Correlations } \\
\hline PEOU1 & PEOU2 PEOU3 PEOU4T_PEOU \\
\hline T_PEOU Pearson &, $866^{* *}$ &, $849^{* *}$ &, $881^{* *}$ &, $888^{* *}$ & 1 \\
Correlation & & & & & \\
Sig. (2-tailed) &, 000 &, 000 &, 000 &, 000 & \\
N & 126 & 126 & 126 & 126 & 126 \\
\hline
\end{tabular}

**. Correlation is significant at the 0.01 level (2-tailed).

Tabel 11. Uji Pearson Variabel Behavioral Intention to Use Correlations

BITU1 BITU2 BITU3 BITU4 T_BITU

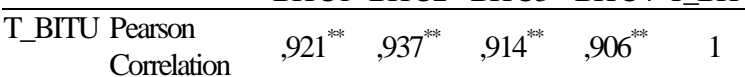

Sig. (2-tailed) $\quad, 000 \quad, 000 \quad, 000 \quad, 000$

$\begin{array}{llllll}\mathrm{N} & 126 & 126 & 126 & 126 & 126\end{array}$

**. Correlation is significant at the 0.01 level (2-tailed).

Tabel 12. Uji Pearson Variabel Trust

Correlations

\begin{tabular}{llccccc}
\hline & & T1 & T2 & T3 & T4 & T_T \\
\hline T_T & Pearson Correlation &, $890^{3 *}$ &, $919^{3 *}$ &, $844^{3 * *}$ &, $884^{3 *}$ & 1 \\
& Sig. (2-tailed) &, 000 &, 000 &, 000 &, 000 & \\
& N & 126 & 126 & 126 & 126 & 126 \\
\hline
\end{tabular}

**. Correlation is significant at the 0.01 level (2-tailed). 
Tabel 13. Uji Pearson Variabel Computer Self Efficacy

\begin{tabular}{lcclll}
\multicolumn{7}{c}{ Correlations } \\
\hline \multicolumn{7}{c}{ CSE1 } & CSE2 & CSE3 & CSE4 & T_CSE \\
\hline T_CSE Pearson &, $826^{* *}$ &, $875^{* *}$ &, $909^{* *}$ &, $876^{* *}$ & 1 \\
Correlation & & & & & \\
Sig. (2-tailed) &, 000 &, 000 &, 000 &, 000 & \\
N & 126 & 126 & 126 & 126 & 126 \\
\hline **. Correlation is significant at the 0.01 level (2-tailed).
\end{tabular}

Tabel 14. Uji Pearson Antar Seluruh Variabel

\begin{tabular}{llccccc}
\hline & & PU & PEOU BITU & T & CSE \\
\hline PU & Pearson Correlation & 1 & & & & \\
& Sig. (2-tailed) & & & & & \\
& N & 126 & & & & \\
\hline PEOU Pearson Correlation &, $879^{* * *}$ & 1 & & & \\
& Sig. (2-tailed) &, 000 & & & & \\
& N & 126 & 126 & & & \\
\hline BITU & Pearson Correlation &, $810^{* * *}$ &, $837^{* * *}$ & 1 & & \\
& Sig. (2-tailed) &, 000 &, 000 s & & & \\
& N & 126 & 126 & 126 & & \\
\hline T & Pearson Correlation &, $749^{* * *}$ &, $807^{* * *}$ &, 806 & 1 & \\
& Sig. (2-tailed) &, 000 &, 000 &, 000 & & \\
& N & 126 & 126 & 126 & 126 & \\
\hline CSE & Pearson Correlation &, $743^{* * *}$ &, $800^{* * *}$ &, $719^{* * *}$ &, $854^{* * *}$ & 1 \\
& Sig. (2-tailed) &, 000 &, 000 &, 000 &, 000 & \\
& N & 126 & 126 & 126 & 126 & 126 \\
\hline
\end{tabular}

Hasil Uji antar seluruh variabel menunjukkan bahwa seluruh variabel yang dihipotesiskan memiliki korelasi satu sama lain.

\section{Uji Reliabilitas}

Uji Relibilitas adalah suatu tingkatan yang mengukur konsistensi hasil, jika dilakukan pengukuran berulan pada suatu karakteristik. Pengujian relibilitas dapat dihitung dengan menggunakan Cronbach alpha. Variabel dapat dikatakan valid apabila nilai dari Cronbach alpha >0,70. Setelah diuji diperoleh nilai Cronbach Alpha untuk data ini seperti pada Tabel 15.

Tabel 15. Uji Reliabilitas untuk seluruh Variabel

\begin{tabular}{cc}
\hline Variabel & Angka Cronbach Alpha \\
\hline Trust & 0.907 \\
Computer Self Efficacy & 0.893 \\
Perceived Usefulness & 0.880 \\
Perceived Ease of Use & 0.893 \\
Behavioral Intention to Use & 0.938 \\
\hline
\end{tabular}

Hasil yang diperoleh adalah semua variabel memiliki data yang reliabel untuk digunakan dalam penelitian ini karena nilai yang diperoleh berada diatas 0.7 .

\section{Uji Model Fit Menggunakan Sofware SPSS AMOS}

Pada Gambar 2 ini merupakan model awal yang dibuat di AMOS.

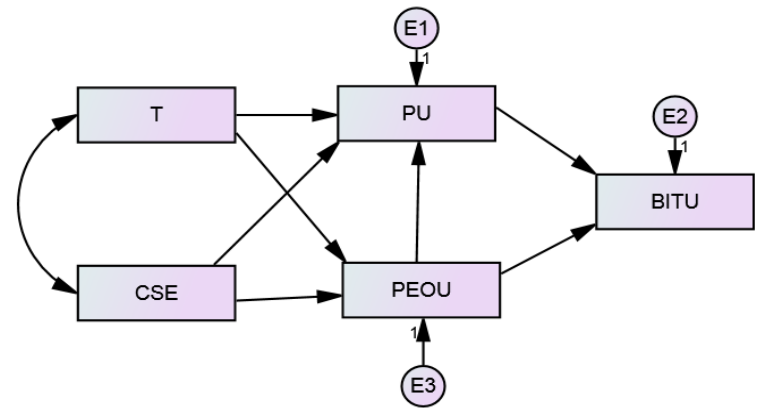

Gambar 2. Model awal AMOS

Setelah menganilisa model awal AMOS yang telah dibuat, maka dapat dilihat hasil Uji Model fit pada Tabel 16.

Tabel 16. Uji Model FIT Awal

\begin{tabular}{lccc}
\hline \multicolumn{1}{c}{ Model Fit } & $\begin{array}{c}\text { Nilai yang } \\
\text { diharapkan }\end{array}$ & $\begin{array}{c}\text { Nilai yang } \\
\text { dicapai }\end{array}$ & Kesimpulan \\
\hline Chi Square & $\begin{array}{l}\text { Diharapkan angka } \\
\text { kecil dengan } \mathrm{p} \geq 0.05\end{array}$ & $\begin{array}{c}22,157 \text { dan } \\
0,00\end{array}$ & Kurang baik \\
& $\leq 3$ & 11,079 & Kurang Baik \\
$\begin{array}{l}\text { Normed Chi } \\
\text { Square }\end{array}$ & Mendekati nol & 0,21 & Kurang baik \\
$\begin{array}{l}\text { RMR (Root } \\
\text { mean Square }\end{array}$ & & 0,939 & Baik \\
$\begin{array}{l}\text { Residual) } \\
\text { GFI (goodness of }\end{array}$ & $\geq 0.90$ & 0,542 & Kurang baik \\
$\begin{array}{l}\text { Fit index) } \\
\text { AGFI (adjusted }\end{array}$ & $\geq 0.90$ & 0,968 & Baik \\
$\begin{array}{l}\text { GFI) } \\
\text { NFI (Normal Fit }\end{array}$ & $\geq 0.90$ & 0,970 & Baik \\
$\begin{array}{l}\text { Index) } \\
\text { IFI (Incremental }\end{array}$ & $\geq 0.90$ & 0,970 & Baik \\
$\begin{array}{l}\text { Fit Index) } \\
\text { CFI } \\
\text { (Comparative Fit }\end{array}$ & $\geq 0.90$ & & \\
$\begin{array}{l}\text { Index) } \\
\text { RMSEA (Root } \\
\text { Mean Square } \\
\text { Error of } \\
\text { Approximation) }\end{array}$ & $\leq 0.05$ & 0,284 & Kurang Baik \\
\hline
\end{tabular}

Dapat dilihat hasil Uji Model fit pada Tabel 16 masih banyak nilai yang dicapai untuk mencapai nilai yang diharapkan masih kurang baik.

\section{Modifikasi Model}

Berdasarkan hasil Uji Model Fit pada Tabel 16, masih ada aspek yang belum sesuai dengan nilai yang diharapkan. Oleh karena itu, dilakukan modifikasi pada model yang sesuai dengan saran yang diberikan oleh Program AMOS. AMOS menyarankan untuk menambahkan 1 hubungan lagi yaitu hubungan $\mathrm{T} \rightarrow$ BITU pada Tabel 17:

Regression Weights: (Group number 1 - Default model)

Tabel 17. Saran yang diberikan oleh Program AMOS

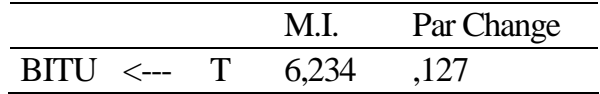


Setelah melakukan penambahan pada 1 jalur tersebut, terdapat 2 hubungan jalur yang tidak signifikan yaitu $\mathrm{T} \rightarrow \mathrm{PU}$, Nilai $\mathrm{P}$ yang menunjukkan nilai 0,409 dan jalur $\mathrm{CSE} \rightarrow \mathrm{PU}$ dengan nilai $\mathrm{P}$ 0,429, sehingan hubungan jalur tersebut dihilangkan.

Gambar 3 adalah pemodelan akhir yang telah dimodifikasi di AMOS.

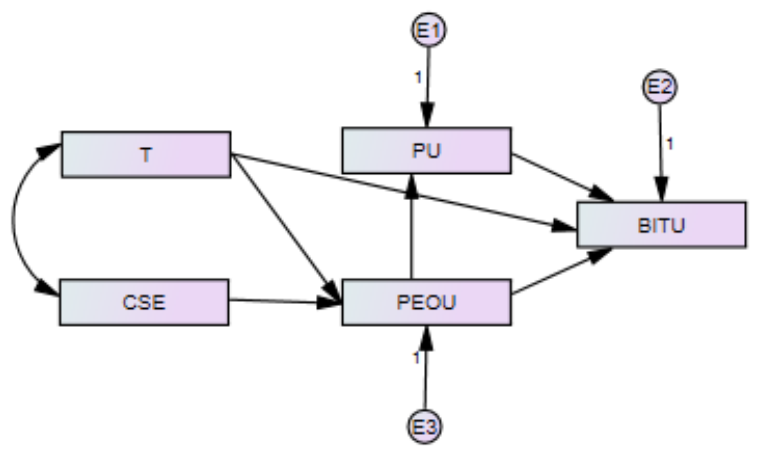

Gambar 3. Setelah hubungan $\mathrm{T} \rightarrow \mathrm{PU}$ dan $\mathrm{CSE} \rightarrow \mathrm{PU}$ dihapus dan penambahan jalur $\mathrm{T} \rightarrow \mathrm{BITU}$

Pada Gambar 3 terlihat bahwa terdapat tambahan 1 hubungan, yaitu $\mathrm{T} \rightarrow$ BITU. Selain itu terdapat pengrangan 2 hubungan langsung yaitu $\mathrm{T} \rightarrow \mathrm{PU}$ dan $\mathrm{CSE} \rightarrow \mathrm{PU}$. Dari penambahan tersebut maka hasil dari model fit berubah. Perubahan tersebut dapat dilihat pada Tabel 18.

Tabel 18. Hasil Uji Model Fit setelah dimodifikasi

\begin{tabular}{|c|c|c|c|}
\hline Model Fit & $\begin{array}{c}\text { Nilai yang } \\
\text { diharapkan }\end{array}$ & $\begin{array}{c}\text { Nilai yang } \\
\text { dicapai }\end{array}$ & $\begin{array}{l}\text { Kesim- } \\
\text { pulan }\end{array}$ \\
\hline Chi Square & $\begin{array}{c}\text { Diharapkan angka } \\
\text { kecil dengan } \mathrm{p} \geq \\
0.05\end{array}$ & $\begin{array}{l}5,55 \text { dan } \\
0,13\end{array}$ & Baik \\
\hline $\begin{array}{l}\text { Normed Chi } \\
\text { Square }\end{array}$ & $\leq 3$ & 1,85 & Baik \\
\hline $\begin{array}{l}\text { RMR (Root mean } \\
\text { Square Residual) }\end{array}$ & Mendekati nol & 0,01 & Baik \\
\hline $\begin{array}{l}\text { GFI (goodness of } \\
\text { Fit index) }\end{array}$ & $\geq 0.90$ & 0,98 & Baik \\
\hline $\begin{array}{l}\text { AGFI (adjusted } \\
\text { GFI) }\end{array}$ & $\geq 0.90$ & 0,91 & Baik \\
\hline $\begin{array}{l}\text { NFI (Normal Fit } \\
\text { Index) }\end{array}$ & $\geq 0.90$ & 0,99 & Baik \\
\hline $\begin{array}{l}\text { IFI (Incremental } \\
\text { Fit Index) }\end{array}$ & $\geq 0.90$ & 0,99 & Baik \\
\hline $\begin{array}{l}\text { CFI (Comparative } \\
\text { Fit Index) }\end{array}$ & $\geq 0.90$ & 0,99 & Baik \\
\hline $\begin{array}{l}\text { RMSEA (Root } \\
\text { Mean Square Error } \\
\text { of Approximation) }\end{array}$ & $\leq 0.05$ & 0,08 & Baik \\
\hline
\end{tabular}

\section{Analisa Model Akhir}

Pada Tabel 19 ini adalah rangkuman dari seluruh hasil pengaruh langsung, pengaruh tidak langsung, dan pengaruh total dari variabel-variabel model akhir.
Tabel 19. Analisis Pengaruh Model Akhir

\begin{tabular}{lllccc}
\hline \multirow{2}{*}{ Variabel } & \multirow{2}{*}{ Pengaruh } & \multicolumn{3}{c}{ Variabel Endogen } \\
\cline { 3 - 6 } & & & PU & PEOU & BITU \\
\hline Eksogen & $\mathrm{T}$ & Langsung & 0 & 0,425 & 0,371 \\
& & Tidak Langsung & 0,389 & 0 & 0,276 \\
& & Total & 0,389 & 0,425 & 0,649 \\
& \multirow{2}{*}{ CSE } & Langsung & 0 & 0,407 & 0 \\
& & Tidak Langsung & 0,372 & 0 & 0,266 \\
& & Total & 0,372 & 0,407 & 0,266 \\
\hline Intervening & PU & Langsung & 0 & 0,915 & 0,302 \\
& & Tidak Langsung & 0 & 0 & 0 \\
& & Total & 0 & 0,915 & 0,302 \\
& PEOU & Langsung & 0,915 & 0 & 0,378 \\
& & Tidak Langsung & 0 & 0 & 0,276 \\
& & Total & 0,915 & 0 & 0,654 \\
\hline
\end{tabular}

Dari data Tabel 19 menunjukkan pengaruh yang terdapat pada masing-masing variabel. Peneliti menyimpulkan bahwa variabel eksogen terdiri dari $\mathrm{T}$ dan CSE memiliki pengaruh terhadap variabel endogen yaitu PU, PEOU, BITU. Kemudian untuk variabel intervening $\mathrm{PU}$ dan PEOU memiliki pengaruh terhadap variabel endogen BITU.

\section{Komparasi Hasil Penelitian dengan Hipotesis}

Komparasi hasil penelitian ini, terhadap hipotesis yang digunakan untuk menarik kesimpulan dari hasil yang sudah didapatkan. Hasil yang sudah didapat tersebut sudah melalui berbagai uji dan analisa yang dilakukan oleh peneliti. Berdasarkan hasil yang diperoleh, menunjukkan bahwa semua hipotesis terbukti adanya pengaruh signifikan, kecuali hipotesis pertama yaitu Trust secara signifikan berpengaruh negative pada Perceived Usefulness dan hipotesis ketiga yaitu Compuer Self Efficacy secara signifikan berpengaruh negative pada Perceived Usefulness.

\section{KESIMPULAN DAN SARAN}

\section{Kesimpulan}

Dari hasil penelitian yang dilakukan maka dapat disimpulkan sebagai berikut:

1. Semua variabel eksogen dalam penelitian kali ini memiliki pengaruh secara langsung dan tidak langsung terhadap variabel endogen lain.

2. Semua variabel intervening dalam penelitian kali ini memiliki pengaruh secara langsung dan tidak langsung terhadap variabel endogen lain, kecuali variable PU terhadap PU dan PEOU terhadap PEOU.

3. Variabel T terhadap PU, dan CSE terhadap PU tidak memiliki pengaruh langsung dan hubungan antar variabel tersebut tidak memiliki korelasi yang signifikan.

4. Adanya modifikasi pada model, dikarenakan adanya 1 hubungan yang memiliki korelasi signifikan yaitu $\mathrm{T}$ terhadap BITU, dan masih belum tercapainya nilai goodness of fit yang diharapkan 
sesuai dalam tabel model fit. Dari usulan tersebut maka ditambahkan pengaruh langsung dari 1 hubungan tersebut yaitu T terhadap BITU.

5. Dalam penelitian kali ini, variabel eksogen yang memiliki pengaruh terbesar terhadap variabel lain adalah $\mathrm{T}$ terhadap BITU. Trust/Kepercayaan mempengaruhi seseorang untuk keinginan seseorang untuk menggunakan aplikasi Uber ini. Pengaruh tersebut memiliki nilai standar deviasi 0,649 . Dengan demikian, dapat disimpulkan bahwa semakin tinggi tingkat Trust/Kepercayaan seseorang dalam interaksi terhadap teknologi maka Keinginan seseorang untuk menggunakan terhadap aplikasi Uber meningkat.

\section{Saran}

Beberapa saran yang dapat diberikan kepada pihak-pihak terkait berdasarkan hasil penelitian ini adalah sebagai berikut:

1. Dalam penelitian selanjutnya, diharapkan untuk terus mengembangkan variabel eksternal yang akan digunakan yaitu dengan menggunakan variable lain, sehinga lebih lengkap dan dapat dilihat faktor-faktor apa saja yang memiliki pengaruh terhadap adopsi aplikasi Uber sebagai media bisnis

2. Diharapkan penelitian selanjutnya menargetkan sampel atau responden yang lebih spesifik sehingga penelitian menjadi lebih akurat.

3. Melakukan penelitian terhadap aplikasi popular yang lainnya

\section{DAFTAR PUSTAKA}

[1] Kurniawan, D. (2013). Analisis Penerimaan Nasabah Terhadap Layanan Mobile Banking dengan Menggunakan pendekatan Technology Acceptance Model dan Theory Of Reasoned Action. Jurnal Manajemen Pemasaran, 1.
[2] Rafique, M. (2014). Extending TAM, In Terms of Trust and attitude towards the online shopping intention. Journal of Public Administration and Governance.

[3] Belkhamza. (2012). Measuring Organizational Information Systems Success: New Technologies and practices. Business science Reference.

[4] Poetri, A.R. (2010). Adopsi E-Commerce dengan pendekatan technology. Jurusan Manajemen pada Fakultas Ekonomi Universitas Sebelas Maret.

[5] Anon, A. (2015, June 2). Pengalaman menggunakan App Uber di Bandung - Seputar Android. Retrieved from http://indonesiaberkicau.com/pengalaman-menggunaan-app-uberbandung/

[6] Sari, M. (2016). Pengaruh Manajemen Laba Terhadap Pengungkapan Corporate social Responsibility. Akuntabilitas.

[7] Fitriyani, D. (2015, May 15). Populasi dan Sampel dalam Penelitian Kuantitatif. Retrieved from http://diyahfitriyani94.blogspot.co.id/2015/ 05/populasi-dan-sampel-dalam-penelitian.html

[8] Ghozali, I. (2011). Aplikasi Analisis Multivariate dengan program IBM SPSS 19 (Edisi Kelima). Semarang: Universitas Diponeggoro Semarang.

[9] Agustina, Y. V. (2012). Analisis Pengaruh Kualitas Pelayanan Kepuasan Pelanggan dalam Meningjatkan Loyalitas Pelanggan Joglosemar BUS. Diponegoro Journal of Management.

[10] Sugiyono. (2007). Metode Penelitian Pendidikan, Pendekatan Kuantitatif, Kualitatif, dan R\&D. Bandung: Alfabeta.

[11] Olobatuyi. (2006). A user's guide to path analysis. University Press of America.

[12] Siregar. (2010). Statistika Deskriptif untuk Penelitian. Jakarta: Rajawali Pers. 